\title{
Targeted radiotherapy of neuroblastoma: Future directions
}

\author{
Mathias Tesson ${ }^{1}$, Colin Rae ${ }^{1}$, Donna L Nile ${ }^{1}$, Mark N Gaze ${ }^{2}$ and Robert J Mairs ${ }^{1 *}$ \\ ${ }^{1}$ Radiation Oncology, Institute of Cancer Sciences, University of Glasgow, UK \\ ${ }^{2}$ University College London Hospitals, UK
}

Neuroblastoma is a malignancy predominantly of infancy. It originates most commonly in the adrenal gland and affects a hundred individuals per year in the UK. Half of neuroblastomas are highly aggressive, disseminated throughout the body of the patient and characterised by unresponsiveness to therapy or early relapse if remission is achieved. High-risk neuroblastoma is responsible for $12 \%$ of paediatric cancer fatalities and new treatments are urgently needed [1].

Ninety percent of neuroblastoma tumours express the noradrenaline transporter (NAT). These can be treated with targeted radiotherapy using an iodine-131-radiolabelled drug, meta-iodobenzylguanidine ( ${ }^{131} \mathrm{I}-\mathrm{MIBG}$ ), which is structurally similar to noradrenaline. ${ }^{131} \mathrm{I}-\mathrm{MIBG}$ has produced long-term remission and palliation in patients with resistant disease [2]. However, some neuroblastoma tumours cease expression of NAT, engendering resistance to ${ }^{131} \mathrm{I}-\mathrm{MIBG}$ [2]. This observation prompted the diagnostic and therapeutic application of an alternative radiopharmaceutical - radiolabelled octreotate which targets somatostatin receptors (SSTRs), expressed on human neuroblastoma cells [3-5].

Octreotate linked to the $\beta$-particle-emitting lutetium-177 ${ }^{177} \mathrm{Lu}$ DOTATATE) binds with high affinity to SSTR2. The safe and successful treatment of children with neuroblastoma using ${ }^{177} \mathrm{Lu}$-DOTATATE was recently reported [6,7].

The administration of both ${ }^{131} \mathrm{I}$-MIBG and ${ }^{177} \mathrm{Lu}$-DOTATATE is expected to enhance therapeutic efficacy. Significantly, as the main unfavourable effect of ${ }^{131}$ I-MIBG therapy is myelosuppression whereas that of ${ }^{177} \mathrm{Lu}$-DOTATATE therapy is renal toxicity, the combined treatment with ${ }^{131} \mathrm{I}-\mathrm{MIBG}$ and ${ }^{177} \mathrm{Lu}$-DOTATATE is not expected to intensify adverse effects. In order for a clinical study of the combination of radiopharmaceuticals to proceed, the optimal sequence and timing of administration must be determined. Previous studies indicate that these factors have a profound influence on the efficacy of radionuclide therapy [8].

Following a study of patients with neuroblastoma, nonconcordance between ${ }^{123}$ I-MIBG- and ${ }^{177} \mathrm{Lu}$-DOTATATE-derived images was reported [6], indicating variation between tumors with respect to capacity for radiopharmaceutical uptake. Significantly, it has been shown that the cellular uptake of both radiopharmaceuticals is enhanced by DNA-damaging agents, including ionizing radiation $[9,10]$. If such potentiation of receptor expression pertains also in vivo, the sequencing of administration of radiopharmaceuticals and the interval between injections could have a substantial influence on efficacy.

Radionuclide therapy delivers ionizing radiation at very low dose rate $(\mathrm{LDR})(\leq 2 \mathrm{cGy} / \mathrm{min})$, which decreases with time. The outcome of fractionated administration of ${ }^{131} \mathrm{I}-\mathrm{MIBG}$ and ${ }^{177} \mathrm{Lu}$ DOTATATE cannot be predicted because it depends on the properties of the radionuclide and of the tumor [8,11-16] (Table 1). Therefore, experimental testing is required to determine the optimal scheduling of delivery of these two radiopharmaceuticals.

Two opposing outcomes of sequential administration of radiopharmaceutical are envisaged: (i) prior exposure of tumour cells to one radiopharmaceutical could enhance the expression of the target of the subsequently applied radiopharmaceutical, engendering a positive therapeutic effect; and (ii) a priming dose of radiopharmaceutical may stimulate radioprotective (adaptive) responses in surviving cells thereby reducing the effectiveness of the subsequently delivered radiopharmaceutical. The establishment of the optimal schedule of delivery of radiopharmaceuticals will minimise the capacity of tumours, which do not succumb to initial radiopharmaceutical treatment, to develop resistance to subsequently administered radiotherapy.

Efforts to improve the therapeutic efficacy of targeted radiotherapy by combination with radiosensitisers are now being implemented. Furthermore, the reduction of resistance to targeted radiotherapy by means of combinations of radiopharmaceuticals which bind to alternative targets is likely to translate into the improvement of the management of patients with high risk neuroblastoma.

\section{Acknowledgements}

This work is supported by funding from Children with Cancer UK.

Table 1. Factors influencing the response to radionuclide therapy delivered at low dose and low dose rate.

\begin{tabular}{|l|l|}
\hline Factors that enhance cell kill & Factors that reduce cell kill \\
\hline $\begin{array}{l}\text { Radiation-induced biological bystander } \\
\text { effect }\end{array}$ & $\begin{array}{l}\text { Non-uniformity of tumour uptake of } \\
\text { radiopharmaceuticals due to heterogeneity } \\
\text { of target expression }\end{array}$ \\
\hline Hypersensitivity to low-dose radiation & $\begin{array}{l}\text { Increased radioresistance at low radiation } \\
\text { dose }\end{array}$ \\
\hline Radiation cross-fire & Adaptive response \\
\hline $\begin{array}{l}\text { Redistribution of cells to radiosensitive } \\
\text { phases of the cell cycle and reoxygenation }\end{array}$ & $\begin{array}{l}\text { Sustained repair of DNA damage during } \\
\text { treatment }\end{array}$ \\
\hline
\end{tabular}

Correspondence to: Robert Mairs, Institute of Cancer Sciences, University of Glasgow, Garscube Estate, Glasgow G61 1BD, Scotland, UK, Tel: +44(0)141 330 4126, Fax: +44(0)141 440 4127, E-mail: Robert.Mairs@glasgow.ac.uk

Received: October 15, 2017; Accepted: November 10, 2017; Published: November 13, 2017 


\section{References}

1. Cole KA, Maris JM (2012) New strategies in refractory and recurrent neuroblastoma: translational opportunities to impact patient outcome. Clin Cancer Res 18: 2423-2428. [Crossref]

2. Matthay KK, Yanik G, Messina J, Quach A, Huberty J, et al. (2007). Phase II study on the effect of disease sites, age, and prior therapy on response to iodine-131metaiodobenzylguanidine therapy in refractory neuroblastoma. J Clin Oncol 25: 10541060. [Crossref]

3. Georgantzi K, Tsolakis AV, Stridsberg M, Jakobson A, Christofferson R, Janson ET (2011). Differentiated expression of somatostatin receptor subtypes in experimental models and clinical neuroblastoma. Pediatr Blood Cancer 56: 584-589. [Crossref]

4. Maggi M, Baldi E, Finetti G, Franceschelli F, Brocchi A, et al. (1994). Identification, characterization, and biological activity of somatostatin receptors in human neuroblastoma cell lines. Cancer Res 54: 124-133. [Crossref]

5. O'Dorisio MS1, Chen F, O'Dorisio TM, Wray D, Qualman SJ (1994) Characterization of somatostatin receptors on human neuroblastoma tumors. Cell Growth Differ 5: 1-8. [Crossref]

6. Gains JE, Bomanji JB, Fersht NL, Sullivan T, D'Souza D, et al. (2011) $177 \mathrm{Lu}-$ DOTATATE molecular radiotherapy for childhood neuroblastoma. J Nucl Med 52: 1041-1047. [Crossref]

7. Kong G, Hofman MS, Murray WK, Wilson S, Wood P, et al. (2016) Initial experience with Gallium-68 DOTA-Octreotate PET/CT and peptide receptor radionuclide therapy for pediatric patients with refractory metastatic neuroblastoma. J Pediatr Hematol Oncol 38: 87-96. [Crossref]

8. Mairs RJ, Boyd M (2011) Preclinical assessment of strategies for enhancement of metaiodobenzylguanidine therapy of neuroendocrine tumors. Semin Nucl Med 41: 334 344. [Crossref]
9. Smets LA, Janssen M, Rutgers M, Ritzen K, Buttenhuis C (1991) Pharmacokinetics and intracellular distribution of the tumor-targeted radiopharmaceutical m-iodobenzylguanidine in SK-N-SH neuroblastoma and PC-12 pheochromocytoma cells. Int J Cancer 48: 609-615. [Crossref]

10. Oddstig J, Bernhardt P, Nilsson O, Ahlman H, Forssell-Aronsson E (2006) Radiationinduced upregulation of somatostatin receptor expression in small cell lung cancer in vitro. Nucl Med Biol 33: 841-846. [Crossref]

11. O’Donoghue JA, Bardies M, Wheldon TE (1995) Relationships between tumor size and curability for uniformly targeted therapy with beta-emitting radionuclides. $\mathrm{J} \mathrm{Nucl}$ Med 36: 1902-1909. [Crossref]

12. Joiner MC, Marples B, Lambin P, Short SC, Turesson I (2001) Low-dose hypersensitivity: current status and possible mechanisms. Int J Radiat Oncol Biol Phys 49: 379-389. [Crossref]

13. Boyd M, Ross SC, Dorrens J, Fullerton NE, Tan KW, Zalutsky MR, Mairs RJ (2006) Radiation induced biologic bystander effect elicited in vitro by targeted radiopharmaceuticals labeled with alpha-, beta-, and Auger electron-emitting radionuclides. J Nucl Med 47: 1007-1015. [Crossref]

14. Tang FR, Loke WK (2015) Molecular mechanisms of low dose ionizing radiationinduced hormesis, adaptive responses, radioresistance, bystander effects, and genomic instability. Int J Radiat Biol 91: 13-27. [Crossref]

15. Zhao Y, Zhong R, Sun L, Jia J, Ma S, Liu X (2015) Ionizing radiation-induced adaptive response in fibroblasts under both monolayer and 3-dimensional conditions. PLoS One 10: e0121289. [Crossref]

16. Hall EJ (2006) Radiobiology for the Radiologist. (6 $6^{\text {th }}$ edn). Lippincott Williams \& Wilkins.

Copyright: (C2017 Tesson M. This is an open-access article distributed under the terms of the Creative Commons Attribution License, which permits unrestricted use, distribution, and reproduction in any medium, provided the original author and source are credited. 